\title{
Control of the skin scarring response
}

\author{
LYDIA M. FERREIRA, ALFREDO GRAGNANI, FABIANNE FURTADO \\ and BERNARDO HOCHMAN \\ Programa de Pós-Graduação em Cirurgia Plástica da Universidade Federal de São Paulo, UNIFESP \\ Rua Napoleão de Barros, 715, $4^{\circ}$ andar, 04024-002, São Paulo, SP, Brasil \\ Manuscript received on May 18, 2009; accepted for publication on June 9, 2009; \\ presented by LUIZ R. TRAVASSOS
}

\begin{abstract}
There comes a time when the understanding of the cutaneous healing process becomes essential due to the need for a precocious tissue repair to reduce the physical, social, and psychological morbidity. Advances in the knowledge on the control of interaction among cells, matrix and growth factors will provide more information on the Regenerative Medicine, an emerging area of research in medical bioengineering. However, considering the dynamism and complexity of the cutaneous healing response, it is fundamental to understand the control mechanism exerted by the interaction and synergism of both systems, cutaneous nervous and central nervous, via hypothalamus hypophysis-adrenal axis, a relevant subject, but hardly ever explored. The present study reviews the neuro-immune-endocrine physiology of the skin responsible for its multiple functions and the extreme disturbances of the healing process, like the excess and deficiency of the extracellular matrix deposition.
\end{abstract}

Key words: wound healing, keratinocytes, fibroblasts, keloid, tissue engineering, skin, plastic surgery.

Plastic surgery, a field that is advancing at a rapid pace, is becoming multi- and interdisciplinary by the integration with other medical-surgical specialties, thereby assuring a better care for patients. Due to unquestionable advances, plastic surgery no longer deals only with the correction of congenital and acquired deformities of tissues and organs, but also seeks functional, cosmetic and psychological results in a more holistic manner (Ferreira 2004).

\section{PHYSIOLOGY OF THE SKIN SCARRING RESPONSE}

The skin has an autonomous "Cutaneous Nervous System" (CTNS), or neurosensory system, which is the main responsible for the scarring process, sympathetic stimulus in neurogenic inflammation, and generation of

In commemoration of the $75^{\text {th }}$ anniversary of Escola Paulista de Medicina / Universidade Federal de São Paulo. Correspondence to: Dr. Lydia Masako Ferreira

E-mail: lydia.dcir@epm.br bioelectric currents (Toyoda et al. 1999, Gragnani et al. 2007a). This system consists of sensory cells, melanocytes, and keratinocytes, all of which release neuropeptides, and of immune and endothelial cells. Its functioning process is similar to the central nervous command of the "Hypothalamus-Hypophysis-Adrenal axis" (HHAA) (Lotti et al. 1995, Zouboulis et al. 2002, Ziegler et al. 2007).

When the skin is subjected to environmental stresses, stimuli are transmitted to the "Central Nervous System" (CNS) by afferent peripheral neural signaling. In this situation, the sebaceous glands release corticotropin-releasing hormone (CRH), similar to that released by the hypothalamus (Slominski et al. 2006a, b, Krause et al. 2007). This hormone, through an endocrine pathway, combines with the hypothalamic $\mathrm{CRH}$ and, by acting on the hypophysis, stimulates the "Sympathetic Nervous System" (SNS), consequently increasing the release of proopiomelanocortin (POMC)-derived pep- 
tides, represented by the adrenocorticotrophic hormone (ACTH), melanocyte-stimulating hormone (MSH), and prolactin, a group also known as "stress hormones" (Grützkau et al. 2000, Kono et al. 2001, Slominski et al. 2004).

When an organism is subjected to stress, certain parts of the brain synergistically activate the SNS by stimulating the HHAA (Dhabhar and McEwen 1999). The stress response is transmitted to the organs, and especially to the skin, by the integration with the CNS, through the stimulation of sympathetic nerve fibers that release neurotransmitters and neuropeptides (Slominski and Wortsman 2000, Toyoda et al. 2002).

On the other hand, the activation of the HHAA, via CNS, stimulates the basal layer of sebaceous glands to produce $\mathrm{CRH}$, which in turn provides feedback that stimulates this axis, establishing an equivalence and functional synergism between the HHAA and CTNS (Zouboulis et al. 2002, Krause et al. 2007, Kono et al. 2001, Toyoda et al. 2002, Gauthier 1996, Toyoda and Morohashi 2001). Therefore, the response to stress stimuli from one axis may exacerbate the sympathetic function of the other.

The triggering of the scarring process depends on the directional migration (electrotaxis) of the cells, which is caused by a wound current and the release of neuropeptides by A-delta and $\mathrm{C}$ sensory nerve fibers (Weiss et al. 1990, Schmelz and Petersen 2001, Slominski et al. 1993). These events correspond to the phase of neurogenic inflammation, which will affect the subsequent stages of the scarring process. Hence, electrical, immunological, inflammatory and hormonal responses of the scarring process are neurally modulated (Slominski et al. 1993, Kim et al. 1998). The relationship between cutaneous scarring and peripheral innervation is evidenced by the delay in the healing after sympathectomy (Glaser et al. 1999, Esteves Jr. et al. 2004).

Nerve fibers in synergy with the HHAA and CTNS axes participate in the phase of neurogenic inflammation, allowing psychological influences interrelated to the SNS to interfere with the cutaneous scarring process (Allen et al. 1973). Therefore, in stress situations, sympathetic hyperstimulation leads to hyperactivity of the sweat glands and pilosebaceous units, modifying bioelectrical and neurosecretory properties of the skin, and causing imbalance in the scarring process (Pintér et al. 1997, Zancanaro et al. 1999, Sauerstein et al. 2000, Kimyai-Asadi and Usman 2001, Storm et al. 2002).

A neural imbalance of the scarring process may cause two types of pathological scarring. The first type is characterized by an increase in nerve fibers, pro-inflammatory neuropeptides, and extracellular matrix, corresponding to the fibroproliferative scars (Parkhouse et al. 1992, Crowe et al. 1994, Hochman et al. 2008b). The second type is characterized by a decrease in these parameters, and is represented by burn wounds (Altun et al. 2001).

\section{EXCESS OF EXTRACELLULAR MATRIX: FIBROPROLIFERATIVE SCARS}

Although scarring is usually a beneficial process for the organism, an excessive deposition of some proteins, such as collagen, may cause cosmetic and functional complications, resulting in keloid and hypertrophic scars. Nowadays, hypertrophic scars are considered phenotypic expressions of keloids of lesser intensity (Muir 1990, Placik and Lewis 1992) and, as a group, they are known as fibroproliferative scars (Tredget et al. 1997, Bock and Mrowietz 2002, Rahban and Garner 2003, Hochman and Ferreira 2007). Keloid is a disorder more common in tropical countries. It shows a prevalence of $1.5 \%$ in the US. In Africa, its incidence reaches $16 \%$ (Bock and Mrowietz 2002). Keloid is frequent in Brazil (although there are no statistical data on this subject) probably due to the tropical climate and intense miscegenation of the population (Canary et al. 1990).

Fibroproliferative scars, regardless of their size, have an important aesthetic, social and psychological impact in patients, since they usually occur in more exposed areas (Bock et al. 2006, Clayman et al. 2006, Rusciani et al. 2006). Pain, pruritus, ulcerations and loss of functional capacity add up to the disturbance caused by the deformity when it is located in articular regions (Komarcevic et al. 2000, Bock and Mrowietz 2002, Davies et al. 2004). These symptoms negatively affect factors associated with mental health, such as sleepiness, body image, self-esteem, sexual functioning, and self-confidence, interfering in social functioning and life (Teich Alasia et al. 1996, Bock et al. 2006). Moreover, the lack of efficient preventive measures 
results in elevated medical costs (Davies et al. 2004, Bickers et al. 2006).

Burn patients have a prevalence of hypertrophic scars of about $67 \%$, which leads to high medical costs due to the size of the wound surface area (Bombaro et al. 2003). In Brazil, the highest prevalence of burn injury $(61.4 \%)$ is found in individuals up to 20 years of age, and reaches $23 \%$ in the economically active age group (adults between 20 to 39 years of age). According to these data, the age group that is most at risk of burn injury is coincident with that most at risk of fibroproliferative scars. Therefore, in Brazil, both burn injuries and fibroproliferative scars represent a public health problem (Rossi et al. 1998).

In the field of surgery, problems with fibroproliferative scars are not only restricted to plastic surgery. In thoracic surgery, fibroproliferative scars are a common complication. This occurs because the thoracic wall is at high risk for this type of lesion, and also due to the increasing number of surgical myocardial revascularizations (Manuskiatti and Fitzpatrick 2002). Fibroproliferative scars are common in obstetrics and gynecology, resulting from breast surgeries and cesarean sections (Ishizuka et al. 2007).

The mechanism of scar formation is still not completely understood. Consequently, treatments are palliative, and there are no efficient preventive measures (Keira et al. 2004, Campaner et al. 2006, Hochman et al. 2008b). In the case of keloids, the maximum expression of fibroproliferative scars, the difficulty in understanding their pathogenesis comes from the fact that this condition occurs exclusively in humans (Placik and Lewis 1992, O'Sullivan et al. 1996, Hochman et al. 2004, 2005). Despite this difficulty, there is a consensus that keloid is a benign neoplasia, because it develops in vitro even in the absence of humoral factors (Placik and Lewis 1992, Keira et al. 2004, Hochman et al. 2008a).

It is estimated that $75 \%$ of all dermatopathies are caused by psychophysiological disturbances, because the skin reacts directly to psychoemotional stimuli. The study of the relationship between mind and skin has had a very fast development in the last decades, consolidating the field of science known as psychodermatology (Koo and Lebwohl 2001, Jafferany 2007).
Keloid and hypertrophic scars may also represent somatic manifestations of psychological origin (Barros and Barros 1996). However, despite the interrelation of psychoneurogenic mechanisms with fibroproliferative scars (Liang et al. 2004, Hochman et al. 2008b), these pathological scars still have not been addressed and sufficiently studied as a psychophysiological disturbance.

\section{DEFICIENCY OF EXTRACELLULAR MATRIX: BURN WOUNDS/SKIN BIOENGINEERING}

The development of skin bioengineering is a consequence of the need for permanent wound closure in patients with skin loss. In this type of injury, the wound must be promptly closed to prevent fluid and protein loss, and bacterial invasion (Leigh et al. 1994). Synthetic and biological skin substitutes can be used either for permanent or temporary wound closure. Human cadaver skin allograft is the material most commonly used for temporary wound closure. On the other hand, autologous cultured keratinocytes are used for permanent wound closure (Morgan and Yarmush 1997, Gragnani et al. 2002).

Keratinocytes are responsible for the skin resistance to physical and chemical insults, and skin permeability to the water (Tompkins and Burke 1996). Moreover, keratinocyte growth factor (KGF) mediates the important mitotic activity during the wound healing process (Finch et al. 1995). Keratinocytes also represent an important source of neural growth factor (NGF), which regulates the scarring process by the production and release of sympathetic pro-inflammatory neuropeptides through cutaneous nerve terminals (Niessen et al. 2001).

Keratinocytes subpopulations (stem cells, transit amplifying (TA) cells, and terminally differentiated cells) that are present in the epidermis are capable of self-regeneration and differentiation (Gragnani et al. 2004, 2008, Youn 2004). A fragment of $1 \mathrm{~cm}^{2}$ obtained from normal skin may be expanded more than 5000 times within 3 to 4 weeks, producing enough epithelium to cover the total body surface area of an adult (Gragnani et al. 2004, 2007a, b). In this way, the neo-epithelium provides at the same time skin closure and neural substrates that control homeostasis during wound healing. 
Studies on the behavior of keratinocytes in response to hypoxia, to the lack of glucose, or to both factors, as well as studies on apoptosis and cellular death under different types of insults, and on the use of different substances for the treatment of these deleterious conditions (e.g., antioxidant supplementation) are very important because they enable us to anticipate and prevent problems caused by age, systemic diseases, and local wound conditions at the time of their clinical use (Duarte et al. 2004).

Therefore, research on skin bioengineering is of prime importance for the ideal combination of biomaterials, cultured cells and growth factors in the production of permanent wound closure materials, resulting in an increase in the survival of patients, for instance, with extensive burn wounds (Gragnani et al. 2002, Sobral et al. 2007a, b).

The fundamental advantage of skin substitutes is the possibility of their use as a permanent wound closure, enabling the control of the scarring response by producing larger amounts of a new growth factor, protein or hormone, thereby interfering with the healing process, congenital diseases of the skin, and systemic diseases, such as inhibition of the expression of TGF$\beta_{1}$ (Campaner et al. 2006, Ramos et al. 2008).

\section{RESUMO}

Aproxima-se uma época na qual é fundamental a compreensão do processo cicatricial cutâneo frente à necessidade da restauração tecidual precoce, visando a diminuição das morbidades física, social e psicológica. O avanço no conhecimento acerca do controle das interações entre as células, a matriz e os fatores de crescimento dará maiores informações à Medicina Regenerativa, área de pesquisa emergente da bioengenharia médica. Entretanto, diante do dinamismo e complexidade da resposta cicatricial cutânea torna-se indispensável o entendimento do mecanismo de controle exercido pela interação e sinergismo do sistema nervoso cutâneo e o sistema nervoso central, via eixo hipotálamo-hipófise-adrenal, tema relevante, porém, pouco abordado. O presente estudo revisa a fisiologia neuro-imuno-endócrina da pele, responsável por suas múltiplas funções, e os distúrbios extremos do processo cicatricial, como o excesso e deficiência de deposição da matriz extracelular.
Palavras-chave: cicatrização de feridas, queratinócitos, fibroblastos, engenharia tissular, pele, cirurgia plástica.

\section{REFERENCES}

Allen JA, Armstrong JE and Roddie IC. 1973. The regional distribution of emotional sweating in man. $\mathrm{J}$ Physiol 235: 749-759.

Altun V, Hakvoort TE, van ZuiJlen PP, van Der KWAst TH AND PRENS EP. 2001. Nerve outgrowth and neuropeptide expression during the remodeling of human burn wound scars. A 7-month follow-up study of 22 patients. Burns 27(7): 717-722.

BARROS J AND BARros M. 1996. Cicatrizes hipertróficas y homeopatía. Gac Homeop Caracas 4(2): 73-78.

Bickers DR, Lim HW, MARgolis D, Weinstock MA, Goodman C, Faulkner E, Gould C, Gemmen E AND DALL T. 2006. The burden of skin diseases: 2004. A joint project of the American Academy of Dermatology Association and the Society for Investigative Dermatology. J Am Acad Dermatol 55: 490-500.

Bock O And Mrowietz U. 2002. Keloids. A fibroproliferative disorder of unknown etiology. Hautarzt 53(8): $515-523$

Bock O, Schmid-Ott G, Malewski P And Mrowietz U. 2006. Quality of life of patients with keloid and hypertrophic scarring. Arch Dermatol Res 297(10): 433-438.

Bombaro KM, Engrav LH, Carrougher GJ, Wiechman SA, Faucher L, Costa BA, Heimbach DM, RIVARA FP AND HONARI S. 2003. What is the prevalence of hypertrophic scarring following burns? Burns 29(4): 299-302.

Campaner AB, Ferreira LM, Gragnani A, Bruder JM, CUSICK JL AND MORGAN JR. 2006. Upregulation of TGF-beta1 expression may be necessary but is not sufficient for excessive scarring.J Invest Dermatol 126: 1168-1176.

CANARy PCV, Fillippo R, Pinto LHP AND Aidar S. 1990. Papel da radioterapia no tratamento de quelóides: análise retrospectiva de 267 casos. Rev Bras Cir 80(5): 291-295.

Clayman MA, Clayman SM and Mozingo DW. 2006. The use of collagen-glycosaminoglycan copolymer (Integra) for the repair of hypertrophic scars and keloids. J Burn Care Res 27: 404-409.

Crowe R, Parkhouse N, McGrouther D and BurnSTOCK G. 1994. Neuropeptide-containing nerves in pain- 
ful hypertrophic human scar tissue. Br J Dermatol 130: 444-452.

Davies K, Nduka C and Moir G. 2004. Nurse-led management of hypertrophic and keloid scars. Nurs Times 100(5): 40-44.

DHABHAR FS AND MCEWEN BS. 1999. Enhancing versus suppressive effects of stress hormones on skin immune function. Proc Natl Acad Sci USA 96: 1059-1064.

Duarte IS, Gragnani A And Ferreira LM. 2004. Dimethyl sulfoxide and oxidative stress on cultures on culture of human keratinocytes. Can J Plast Surg 12: 13-16.

Esteves JR I, Ferreira LM AND Liebano RE. 2004. Peptídeo relacionado ao gene da calcitonina por iontoforese na viabilidade de retalho cutâneo randômico em ratos. Acta Cir Bras 19: 626-629.

FERREIRA LM. 2004. Cirurgia plástica: uma abordagem antroposófica. Rev Soc Bras Plast 19: 37-40.

Finch PW, Cunha GR, Rubin JS, Wong J AND Ron D. 1995. Pattern of queratinocyte growth factor and keratinocyte growth factor receptor expression during mouse fetal development sugests a role in mediating morphogenetic mesenchymal-epithelial interactions. Dev Dyn 203: 223-240.

GAUTHIER Y. 1996. Stress and skin: experimental approach. Pathol Biol (Paris) 44: 882-887.

Glaser R, Kiecolt-Glaser JK, Marucha PT, MaCCAllum RC, LAskowski BF AND Malarkey WB. 1999. Stress-related changes in proinflammatory cytokine production in wounds. Arch Gen Psychiatry 56: 450-456.

Gragnani A, Morgan JR And Ferreira LM. 2002. Differentiation and barrier formation of a cultured composite skin graft. J Burn Care Rehabil 23: 126-131.

Gragnani A, Morgan JR And Ferreira LM. 2004. Experimental model of cultured skin graft. Acta Cir Bras 19(Suppl 1): 4-10.

Gragnani A, KeIRA SM, Hochman B ANd FERreira LM. 2007a. Cicatrização - Fibroplasia e fatores de crescimento. In: SchOR N, FERrEIRA LM (Eds), Guia de Cirurgia Plástica, Barueri: Manole, São Paulo, SP, Brasil, p. 49-53.

Gragnani A, Sobral CS And Ferreira LM. 2007b. Thermolysin in human cultured keratinocyte isolation. Braz J Biol 67: 105-109.

GragnANi A, IPOLITO MZ, SOBRAL CS, BRUNiALti MK, SALOMÃo R AND FERREIRA LM. 2008. Flow cytometry of human primary epidermal and follicular keratinocytes. Eplasty 19: 8-14.
GrützKaU A, Henz BM, Kirchhof L, Luger T AND ARTUC M. 2000. Alpha-Melanocyte stimulating hormone acts as a selective inducer of secretory functions in human mast cells. Biochem Biophys Res Commun 278: $14-19$.

Hochman B AND Ferreira LM. 2007. Quelóide. In: SCHOR N AND FERreira LM (Eds), Guia de Cirurgia Plástica, Barueri: Manole. São Paulo, SP, Brasil, Cirurgia Plástica, p. 65-74.

Hochman B, Ferreira LM, Vilas BôAs FC AND MARIANO M. 2004. Hamster (Mesocricetus auratus) cheek pouch as an experimental model to investigate human skin and keloid heterologous graft. Acta Cir Bras 19(Suppl 1): 79-88.

Hochman B, Vilas Bôas FC, Mariano M AND FERREIRA LM. 2005. Keloid heterograft in the hamster (Mesocricetus saturate) cheek pouch. Acta Cir Bras 20(3): 200-212.

Hochman B, Locali RF, MATSUOKA PK AND FERREIRA LM. 2008a. Intralesional triamcinolone acetonide for keloid treatment: a systematic review. Aesthetic Plast Surg 32: 705-709.

Hochman B, Nahas FX, Sobral CS, Arias V, Locali RF, Juliano Y AND FERreira LM. 2008b. Nerve fibers: a possible role in keloid pathogenesis. Br J Dermatol 158: 651-652.

ISHIZUKA CK, ITAMOTO KY, HOCHMAN B AND FERREIRA LM. 2007. Cicatriz hipertrófica. In: SCHOR N AND FERREIRA LM (Eds), Guia de Cirurgia Plástica, Barueri: Manole, São Paulo, SP, Brasil, p. 55-63.

JAFFERANY M. 2007. Psychodermatology: a guide to understanding common psychocutaneous disorders. Prim Care Companion J Clin Psychiatry 9(3): 203-213.

Keira SM, Ferreira LM, Gragnani A, Duarte IS AND BARBosA J. 2004. Experimental model for collagen estimation in cell culture. Acta Cir Bras 19(Suppl 1): $17-22$.

Kim LR, Whelpdale K, Zurowski M And Pomeranz B. 1998. Sympathetic denervation impairs epidermal healing in cutaneous wounds. Wound Rep Reg 6(3): 194201.

Kimyai-Asadi A And Usman A. 2001. The role of psychological stress in skin disease. J Cutan Med Surg 5(2): $140-145$.

Komarcevic A, Pejakov L and Komarcevic M. 2000. New views on the physiology of wound healing. Med Pregl 53(9-10): 479-483. 
Kono M, Nagata H, Umemura S, KaWAna S AND OSAMURA RY. 2001. In situ expression of corticotropin-releasing hormone (CRH) and proopiomelanocortin (POMC) genes in human skin. FASEB J 15: 2297-2299.

Koo J And LeBwohl A. 2001. Psycho dermatology: the mind and skin connection. Am Fam Physician 64: 18731878 .

Krause K, Schnitger A, Fimmel S, Glass E And ZoubOULIS CC. 2007. Corticotropin-releasing hormone skin signaling is receptor-mediated and is predominant in the sebaceous glands. Horm Metab Res 39(2): 166-170.

LEIGH IM, LANE EB AND WatT FM. 1994. The Keratinocyte Handbook. Cambridge: University Press, 566 p.

Liang Z, Engrav lH, Muangman P, Muffley LA, ZHU KQ, CARrougher GJL, Underwood RA AND GIBRAN NS. 2004. Nerve quantification in female red Duroc pig (FRDP) scar compared to human hypertrophic scar. Burns 30: 57-64.

LotTi T, HaUtmann G ANd PANCONESi E. 1995. Neuropeptides in skin. J Am Acad Dermatol 33: 482-496.

MANUSKIATTI W AND FitzPATRICK RE. 2002. Treatment response of keloidal and hypertrophic sternotomy scars: comparison among intralesional corticosteroid, 5-fluorouracil, and 585-nm flashlamp-pumped pulsed-dye laser treatments. Arch Dermatol 138: 1149-1155.

MORGAN JR AND YARMUSH ML. 1997. Bioengineered skin substitutes. Sci Med 4(4): 6-15.

MUIR IFK. 1990. On the nature of keloid and hypertrophic scars. Br J Plast Surg 43: 61-69.

Niessen FB, Andriessen MP, Schalkwijk J, Visser L AND TIMENS W. 2001. Keratinocyte-derived growth factors play a role in the formation of hypertrophic scars. J Pathol 94: 207-216.

O'Sullivan ST, O'Shaughnessy M AND O'CONNOR TP. 1996. Aetiology and management of hypertrophic scars and keloids. Ann R Coll Surg Engl 78(3Pt1): 168175.

Parkhouse N, Crowe R, McGrouther DA And BurnSTOCK G. 1992. Painful hypertrophic scarring and neuropeptides [letter]. Lancet 340: 1410.

Pintér E, Helyes Z, Pethö G And Szolcsányi J. 1997. Noradrenergic and peptidergic sympathetic regulation of cutaneous microcirculation in the rat. Eur $\mathrm{J}$ Pharmacol 325: $57-64$.

PLACIK OJ AND LEWIS VL JR. 1992. Immunologic associations of keloids. Surg Gynecol Obstet 175(2): 185-193.
RAHBAN SR AND GARNER WL. 2003. Fibroproliferative scars. Clin Plast Surg 30: 77-89.

RAmos ML, Gragnani A AND FERreira LM. 2008. Is there an ideal animal model to study hypertrophic scarring? J Burn Care Res 29: 363-368.

Rossi LA, BARRUFFINI RCP, GARCIA TR AND CHIANCA TCM. 1998. Queimaduras: características dos casos tratados em um hospital escola em Ribeirão Preto (SP), Brasil. Rev Panam Salud Pública 4(6): 401-404.

Rusciani L, Paradisi A, Alfano C, Chiummariello S AND RUSCIANI A. 2006. Cryotherapy in the treatment of keloids. J Drugs Dermatol 5(7): 591-595.

Sauerstein K, Klede M, Hilliges M And Schmelz M. 2000. Electrically evoked neuropeptide release and neurogenic inflammation differ between rat and human skin. J Physiol 529: 803-810.

Schmelz M ANd Petersen LJ. 2001. Neurogenic inflammation in human and rodent skin. News Physiol Sci 16: $33-37$.

Slominski A AND WortSman J. 2000. Neuroendocrinology of the skin. Endocr Rev 21(5): 457-487.

Slominski A, Paus R And Schadendorf D. 1993. Melanocytes as "sensory" and regulatory cells in the epidermis. J Theor Biol 164: 103-120.

Slominski A, Tobin DJ, Shibahara S AND Wortsman J. 2004. Melanin pigmentation in mammalian skin and its hormonal regulation. Physiol Rev 84: 1155-1228.

Slominski A, ZBYtek B, PisArchiK A, SLOMINSKi RM, ZMIJEWSKI MA AND WORTSMAN J. 2006a. CRH functions as a growth factor/cytokine in the skin. J Cell Physiol 206: 780-791.

Slominski A, ZBytek B, ZMiJewski M, Slominski RM, Kauser S, Wortsman J AND TOBIn DJ. 2006b. Corticotropin releasing hormone and the skin. Front Biosci 11: 2230-2248.

Sobral CS, Gragnani A, Morgan J And Ferreira LM. 2007a. Inhibition of proliferation of Pseudomonas aeruginosa by KGF in an experimental burn model using human cultured keratinocytes. Burns 33: 613-620.

Sobral CS, Gragnani A, CaO X, Morgan JR and FERREIRA LM. 2007b. Human keratinocytes cultured on collagen matrix used as an experimental burn model. J Burns Wounds 30: 37.

Storm H, Myre K, Rostrup M, Stokland O, Lien MD AND RAEDER JC. 2002. Skin conductance correlates with perioperative stress. Acta Anaesthesiol Scand 46: 887-895. 
Teich Alasia S, Castagnoli C, Calcagni M and Stella M. 1996. The influence of progress in the treatment of severe burns on the quality of life. Acta Chir Plast 38(4): 119-121.

TOMPKINS RG AND BURKE JF. 1996. Alternative Wound Coverings. In: HENDON DN (Ed), Total Burn Care, Philadelphia: W.B. Saunders Company, Philadelphia, USA, p. 164-172.

Toyoda M And Morohashi M. 2001. Pathogenesis of acne. Med Electron Microsc 34: 29-40.

Toyoda M, Luo Y, Makino T, Matsui C And MoroHASHI M. 1999. Calcitonin Gene-Relates Peptide upregulates melanogenesis and enhances melanocyte dendricity via induction of keratinocyte-derived melanotrophic factors. J Invest Dermatol Symp Proc 4(2): 116-125.

Toyoda M, Nakamura M, Makino T, Kagoura M AND Morohashi M. 2002. Sebaceous glands in acne patients express high levels of neutral endopeptidase. Exp Dermatol 11(3): 241-247.

Tredget EE, Nedelec B, Scott PG and Ghahary A. 1997. Hypertrophic scars, keloids and contractures. Surg Clin North Am 77: 701-731.
WEISS DS, KiRSNER R AND EAGLSTEIN WH. 1990. Electrical Stimulation and Wound Healing. Arch Dermatol 126: $222-225$.

Youn SW, Kin DS, Cho HJ, JeON SE, BAE IH, Yoon HJ AND PARK KC. 2004. Cellular senescence induced loss of stem cell proportion in skin in vitro. J Dermatol Sci 35: 113-123.

Zancanaro C, Merigo F, Crescimanno C, OrlanDINI S AND OSCULATI A. 1999. Immunohistochemical evidence suggests intrinsic regulatory activity of human eccrine sweat glands. J Anat 194: 433-444.

Ziegler CG, KRUG AW, Zouboulis CC AND BorNSTEIN SR. 2007. Corticotropin releasing hormone and its function in the skin. Horm Metab Res 39(2): 106-109.

Zouboulis CC, Seltmann H, Hiroi N, Chen W, Young M, OefF M, Scherbaum WA, Orfanos CE, MCCANN SM AND BornsteIn SR. 2002. Corticotropin-releasing hormone: an autocrine hormone that promotes lipogenesis in human sebocytes. Proc Natl Acad Sci USA 99: 7148-7153. 